\author{
Aleksandra Paprot-Wielopolska \\ aleksandra.paprot-wielopolska@ug.edu.pl \\ Instytut Archeologii i Etnologii \\ Uniwersytet Gdański \\ ORCID: 0000-0002-9637-1775
}

\title{
„MY TEŻ CHCEMY MIEĆ SWOJE TRADYCJE”. METODY BADAŃ, DEFINIOWANIE I PRAKTYKOWANIE NIEMATERIALNEGO DZIEDZICTWA KULTUROWEGO NA ZIEMIACH ZACHODNICH I PÓLNOCNYCH
}

\begin{abstract}
„We also want to have our own traditions". Research methods, defining and practicing intangible cultural heritage in the Polish Western and Northern Territories
\end{abstract}

Streszczenie: Tekst skupia się na pomijanym dotychczas niematerialnym dziedzictwie kulturowym (NDK) na Ziemiach Zachodnich i Północnych, które tworzą neoregiony, czyli obszary, gdzie doszło do wielkich migracji ludności w wyniku II wojny światowej. Celem artykułu jest 1) określenie sposobów (metod) rozpoznawania tradycji jako NDK neoregionów we współpracy ze społecznościami lokalnymi i 2) uznania go za element niezbędny w kształtowaniu tożsamości mieszkańców terenów postmigracyjnych. Oparciem dla wyrażonego postulatu jest analiza metod i technik badawczych zastosowanych w projektach realizowanych w wybranych regionach. Służą one zaświadczeniu ich wszechobecności i doniosłej roli w kształtowaniu NDK. Dlatego przeprowadzono krytyczną analizę metod badawczych i ocenę krajowego systemu ochrony NDK oraz przedstawiono możliwości praktycznego zastosowania wyników badań w społecznościach lokalnych na rzecz eksperckiego wsparcia i włączenia go do krajowego rejestru NDK. 
Słowa kluczowe: niematerialne dziedzictwo kulturowe, zarządzanie dziedzictwem kulturowym, Ziemie Zachodnie i Północne, metody badań terenowych

Abstract: The text focuses on the intangible cultural heritage (ICH) in the Polish Western and Northern Territories that have been overlooked so far. They form neoregions, i.e. areas where there was a great migration of people as a result of World War II. The aim of the article is 1) to define ways (methods) of recognizing tradition as the ICH of neoregions in cooperation with local communities, and 2) to recognize it as an essential element in creating the identity of residents of post-migration areas. Analysis of research methods and techniques used in projects implemented in selected regions is the basis for the expressed postulate. They serve to certify their omnipresence and important role in shaping ICH. Therefore, a critical analysis of research methods and evaluation of the national system of ICH protection was carried out and the possibilities of practical application of research results in local communities for expert support and inclusion in the national ICH register were presented.

Key words: intangible cultural heritage, cultural heritage management, the Polish Western and Northern Territories, field research methods

\section{Wprowadzenie}

Od kiedy Polska w 2011 r. ratyfikowała Konwencję UNESCO w sprawie niematerialnego dziedzictwa kulturowego (dalej w tekście: NDK), sporządzoną w 2003 r., w kraju nie ustaje debata na temat wszelkiego rodzaju zjawisk kulturowych uznawanych przez lokalne społeczności i instytucje za „tradycyjne”. Dotychczas zorganizowano wiele spotkań, konferencji, warsztatów, które angażowały różnego rodzaju specjalistów i ekspertów z rządowych oraz wojewódzkich instytucji, naukowców, animatorów kultury, a przede wszystkim wybranych przedstawicieli środowisk lokalnych jako depozytariuszy NDK. Już podczas pierwszych konferencji i debat pojawiały się głosy dotyczące tego, że zapisy Konwencji 
„My też chcemy mieć swoje tradycje”...

w pewnym zakresie nie przystają do realiów obszarów, które zostały przyłączone do Polski po II wojnie światowej, a stanowią obecnie ok. 33\% powierzchni kraju (Paprot 2013). W wątpliwość podawano głównie zapis dotyczący międzypokoleniowego przekazu kulturowego jako nadrzędnego czynnika definiującego NDK, które:

jest stale odtwarzane przez wspólnoty i grupy w relacji z ich otoczeniem, oddziaływaniem przyrody i ich historią oraz zapewnia im poczucie tożsamości i ciągłości, przyczyniając się w ten sposób do wzrostu poszanowania dla różnorodności kulturowej oraz ludzkiej kreatywności ${ }^{1}$.

Definicja ta zawiera bowiem element w jakiś sposób wykluczający dziedzictwo społeczności postmigracyjnych, które obecnie zamieszkują Ziemie Zachodnie i Północne (ZZiP) (por. Sakson 2005). Wiąże się to z tym, że po zakończeniu II wojny światowej na te tereny przybyli nowi osadnicy m.in. z Kresów Wschodnich, regionów centralnych i południowo-wschodnich Polski, Ukraińcy przesiedleni w ramach akcji „Wisła”, a także zesłańcy powracający z głębi ZSRR czy reemigranci i robotnicy przymusowi z Niemiec. Równolegle trwał proces wysiedlania z tych terenów ludności rodzimej, głównie pochodzenia niemieckiego, która była depozytariuszami miejscowych tradycji ujawniających się w wymiarze etnicznym i narodowym, wyznaniowym, a także lokalnym czy regionalnym. Z kolei ludność napływowa przywiozła ze sobą własny bagaż doświadczeń, w tym NDK, które funkcjonowało dotychczas w zupełnie innych realiach społecznych, kulturowych czy środowiskowych, a nagle zostało osadzone w obcym i niezrozumiałym krajobrazie kulturowym (Szyfer 2006; Posern-Zieliński 2005; Brzezińska, Wosińska 2009; Sakson 2011). Rozbicie wspólnot i grup tradycyjnych, które kształtowały się w wyniku specyficznych procesów osadniczych i historycznych zarówno w przypadku ludności wysiedlanej przymusowo z ZZiP, jak i ludności masowo migrującej na te tereny, sprawiło, że ich NDK zaczęło zyskiwać na tych terenach zupełnie nowe znaczenie (Angutek 2018).

Współcześnie owo dziedzictwo stanowi jeden z najważniejszych czynników wpływających na kształtowanie nowych tożsamości mieszkańców obszarów postmigracyjnych w Polsce i wytwarzanie wspólnotowości w neoregionach, czyli obszarach, gdzie nowe wspólnoty kształtują się

1 https://www.unesco.pl/fileadmin/user_upload/pdf/Konwencja_o_ochronie_dz._ niemater_2003.pdf (dostęp: 3.05.2020). 
wśród ludzi, którzy zasiedlili je w wyniku wielkich migracji grup i jednostek (Kubiak 2007: 100). Społeczności lokalne i zbiorowości regionalne podejmują się rekonstrukcji czy odtwarzania tradycji dawnych, charakterystycznych dla tych ziem przed 1945 r., tworzą tradycje nowe - wynalezione po 1945 r. - lub kreują takie, które są pewnego rodzaju kompilacją starych i nowych tradycji (na zasadzie negocjacji kulturowej) (Hobsbawm 2008; Ciechorska-Kulesza 2009; Kwaśniewska 2016; Angutek 2018; Kurpiel 2018). NDK na ZZiP jest więc pewnego rodzaju „materiałem podstawowym" dla społeczności lokalnych, ale też różnego rodzaju instytucji samorządowych, instytucji kultury oraz organizacji i stowarzyszeń, które mają na celu realizowanie mniej lub bardziej sformalizowanych działań pozwalających tworzyć nową tożsamość miejsca i zamieszkujących go ludzi, a także wzmacniać jego potencjał turystyczny, marketingowy i ekonomiczny (Murzyn-Kupisz 2010: 23-26; Santera-Szeliga 2017: 149-152). Jest to szczególnie ważne dla mieszkańców obszarów postmigracyjnych i tamtejszych elit lokalnych oraz regionalnych ${ }^{2}$, dla których wzorem do naśladowania są regiony o kulturze długiego trwania i wyraźnych tradycjach, związanych przede wszystkim z dziedzictwem kultury ludowej i tradycyjnej.

W odniesieniu do powyższych rozważań uważam, że zainteresowanie badaczy z zakresu nauk humanistycznych oraz społecznych powinno skupić się obecnie na tym, w jaki sposób mieszkańcy oraz wspomniane elity ZZiP pojmują współcześnie NDK, jak poszukują jego źródeł i jak je praktykują. Dlatego nadrzędnym celem tekstu jest naukowa „petycja” o docenienie i uwzględnienie NDK, które aktualnie odradza się i jest przez nich wynajdywane, oraz wskazanie, że wpis na krajową listę NDK nie powinien być jedynym wyznacznikiem dla jego pozytywnego wartościowania. Odnosząc się do własnych doświadczeń zarówno jako badaczki tych terenów, jak i działaczki na rzecz regionalnego dziedzictwa, dokonam $\mathrm{w}$ artykule analizy zestawienia własnych metod i technik badawczych re-

${ }^{2}$ Przez wyrażenie ,elity lokalne i regionalne” pojmuję wyspecjalizowane w pewien sposób środowiska grup eksperckich tzn. przedstawicieli instytucji samorządowych i kultury, organizacji oraz regionalistów i działaczy lokalnych, którzy mają często decydujący głos, a tym samym większą sprawczość w kształtowaniu ruchu regionalnego na ZZiP. Według mnie istotne jest rozróżnienie na mieszkańców i elity ZZiP, ponieważ ich wizje i potrzeby nie zawsze są ze sobą zbieżne, przez co trudno mówić niekiedy o nich łącznie jako o wspólnocie. Nie oznacza to jednak, że deprecjonuję stanowisko elit lub nie dostrzegam możliwości egalitarnego funkcjonowania obu grup (mieszkańców i ekspertów). 
„My też chcemy mieć swoje tradycje”...

alizowanych w ramach projektów naukowych, popularno-naukowych lub popularyzatorskich w kontekście rozpoznawania przez lokalne i regionalne społeczności tradycji jako NDK oraz upowszechniania ich. Materiał badawczy zaświadczy o ich bogactwie, niezbywalności oraz sposobach ich badania, a także o współtworzeniu NDK przez badacza (wcielającego się najpierw w uczestnika kultury, potem zdystansowanego badacza). Przyjmuję bowiem, że NDK jest elementem niezbędnym do kształtowania tożsamości społeczności postmigracyjnych.

\section{Projekty, metody i techniki badań oraz ich efekty}

Przedmiotem analizy będzie pięć projektów (dwa naukowe, dwa popularnonaukowe i jeden popularyzatorski), które w latach 2014-2018 realizowałam w charakterze kierownika lub głównego wykonawcy na Pomorzu Zachodnim, Żuławach, Powiślu, Warmii i Mazurach jako regionach wchodzących w skład ZZiP. Większość z nich pośrednio lub bezpośrednio dotyczyła NDK, które było rozpoznawane, opisywane, a niekiedy oceniane przez rozmówców - depozytariuszy lub obserwatorów kultury lokalnej i regionalnej. Zestawienie projektów ilustruje tabela 1, gdzie przedstawiam je w kontekście źródeł finasowania, podmiotów realizujących oraz stosowanych metod i technik badawczych, a także efektów naukowych i społecznych, co umożliwia ich ocenę w odniesieniu do NDK, w tym: gromadzenia wiedzy i jej systematyzowania oraz rozpoznawania dziedzictwa i jego dokumentowania. W kolejnych częściach artykułu skupię się na omówieniu wybranych aspektów projektów. 
Tabela 1. Zrealizowane projekty na Ziemiach Zachodnich i Północnych. Źródło: opracowanie własne

\begin{tabular}{|c|c|c|c|c|c|}
\hline $\begin{array}{l}\text { Nazwa } \\
\text { projektu }\end{array}$ & $\begin{array}{l}\text { „Kreowanie toż- } \\
\text { samości regio- } \\
\text { nalnej oraz lokal- } \\
\text { nej na Ziemiach } \\
\text { Z a chodnich } \\
\text { i Północnych } \\
\text { (ze szczególnym } \\
\text { uwzględnieniem } \\
\text { Żuław i Powiśla)" }\end{array}$ & $\begin{array}{l}\text { Wielokulturo- } \\
\text { we Pomorze: } \\
\text { Ukraińcy i ich } \\
\text { dziedzict wo } \\
\text { kulturowe na } \\
\text { Żuławach i Po- } \\
\text { wiślu" }\end{array}$ & $\begin{array}{l}\text { "W a r m i o, } \\
\text { quo vadis?" }\end{array}$ & $\begin{array}{l}\text { „Krajobraz kul- } \\
\text { turowy Żuław } \\
\text { a praca rolnika } \\
\text { w narracjach } \\
\text { powojennych } \\
\text { osadników za- } \\
\text { mieszkałych na } \\
\text { obszarach wiej- } \\
\text { skich” }\end{array}$ & $\begin{array}{l}\text { „Tutejsi } \\
\text { trad y c j e } \\
\text { kulturowe } \\
\text { Po mor za } \\
\text { Zachodnie- } \\
\text { go" }\end{array}$ \\
\hline $\begin{array}{l}\text { Źródło } \\
\text { finanso- } \\
\text { wania } \\
\text { i podmiot } \\
\text { realizujący }\end{array}$ & $\begin{array}{l}\text { - Narodowe } \\
\text { Centrum Nauki } \\
\text { - Instytut Etno- } \\
\text { logii i Antro- } \\
\text { pologii Kul- } \\
\text { turowej UAM } \\
\text { - własny grant } \\
\text { badawczy }\end{array}$ & $\begin{array}{l}\text { - Wojewódz- } \\
\text { two Pomorskie } \\
\text { - Stowarzysze- } \\
\text { nie „Kochamy } \\
\text { Żuławy” i Za- } \\
\text { kład Etnologii } \\
\text { i Antropologii } \\
\text { Ku lt urowej } \\
\text { UG }\end{array}$ & $\begin{array}{l}\text { - Minister- } \\
\text { stwo Kultury } \\
\text { i Dziedzic- } \\
\text { twa Narodo- } \\
\text { wego } \\
\text { - Wojewódz- } \\
\text { two Warmiń- } \\
\text { sko-Mazur- } \\
\text { skie } \\
\text { - Centrum } \\
\text { Spotkań Eu- } \\
\text { ropejskich } \\
\text { Światowid } \\
\text { w Elblągu }\end{array}$ & $\begin{array}{l}\text { - Ośrodek „Pa- } \\
\text { mięć i Przy- } \\
\text { s zło ść c we } \\
\text { Wrocławiu - } \\
\text { własny grant } \\
\text { badawczy }\end{array}$ & $\begin{array}{l}\text { - M i n i- } \\
\text { sterstwo } \\
\text { K u l t u r y } \\
\text { i Dziedzic- } \\
\text { twa Naro- } \\
\text { dowego } \\
\text { - Europej- } \\
\text { ski Fun- } \\
\text { dusz Roz- } \\
\text { woju Wsi } \\
\text { Polskiej } \\
\text { i Instytut } \\
\text { R o z w o - } \\
\text { ju Wsi } \\
\text { i Rolnictwa } \\
\text { PAN }\end{array}$ \\
\hline $\begin{array}{l}\text { Lata } \\
\text { realizacji }\end{array}$ & 2014-2017 & 2016 & 2016-2017 & 2018 & 2018 \\
\hline Region & $\begin{array}{l}\text { Żuławy, Powi- } \\
\text { śle, Warmia (po- } \\
\text { wiat braniew- } \\
\text { ski), Mazury } \\
\text { (powiat olecki) }\end{array}$ & $\begin{array}{l}\text { Żuławy } \\
\text { i Powiśle }\end{array}$ & $\begin{array}{c}\text { Warmia } \\
\text { (powiat lidz- } \\
\text { barski) }\end{array}$ & Żuławy & $\begin{array}{l}\text { Pomorze } \\
\text { Zachodnie }\end{array}$ \\
\hline
\end{tabular}


„My też chcemy mieć swoje tradycje”...

\begin{tabular}{|c|c|c|c|c|c|c|}
\hline & $\begin{array}{l}\text { tosowa- } \\
\text { metody } \\
\text { chniki } \\
\text { lawcze }\end{array}$ & $\begin{array}{l}\text { - wywiad swo- } \\
\text { bodny ukierun- } \\
\text { kowany z przed- } \\
\text { stawiciela mi } \\
\text { samorządów, in- } \\
\text { stytucji kultury, } \\
\text { stowarzy szeń } \\
\text { i organizacji } \\
\text { oraz liderów } \\
\text { - obserwacje } \\
\text { uczestniczące } \\
\text { - ankieta dot. } \\
\text { społecznej per- } \\
\text { cepcji polityk } \\
\text { kulturalnych } \\
\text { - mapy mental- } \\
\text { ne regionów } \\
\text { - autoetnografia }\end{array}$ & $\begin{array}{l}\text { - wywiad kwe- } \\
\text { stionariuszowy } \\
\text { dotyczący mię- } \\
\text { dzygeneracyj- } \\
\text { nej transmisji } \\
\text { dziedzictwa } \\
\text { kulturowego } \\
\text { wśród Ukra- } \\
\text { ińców z akcji } \\
\text { "Wisła” i ich } \\
\text { potomków; } \\
\text { - dokumenta- } \\
\text { cja fotograficz- } \\
\text { na }\end{array}$ & $\begin{array}{l}\text { - w y wiad } \\
\text { kwestiona- } \\
\text { ri u s z o w y } \\
\text { doty c zą cy } \\
\text { NDK realizo- } \\
\text { wany wśród } \\
\text { najstarszych } \\
\text { mi es zk ań- } \\
\text { ców, depo- } \\
\text { zytariuszy, } \\
\text { w tym: twór- } \\
\text { ców ludo- } \\
\text { wych i ręko- } \\
\text { d z i e l n i - } \\
\text { ków, lide- } \\
\text { rów i orga- } \\
\text { nizacji spo- } \\
\text { łecznych } \\
\text { - dokumen- } \\
\text { tacja fotogra- } \\
\text { ficzna }\end{array}$ & $\begin{array}{l}\text { - metoda oral } \\
\text { history - narra- } \\
\text { cja biograficzna } \\
\text { z dodatkowym } \\
\text { kwestionariu- } \\
\text { szem pytań } \\
\text { - dokumentacja } \\
\text { fotograficzna } \\
\text { i archiwalna }\end{array}$ & $\begin{array}{l}\text { - metoda } \\
\text { projektu: } \\
\text { szkolenie } \\
\text { i warsztaty } \\
\text { dla nauczy- } \\
\text { cieli z za- } \\
\text { kresu NDK } \\
\text { i badań te- } \\
\text { renowych } \\
\text { - wywiady } \\
\text { o charak- } \\
\text { terze kwe- } \\
\text { stionariu- } \\
\text { s zo w y m, } \\
\text { nieustruk- } \\
\text { turyzowa- } \\
\text { ne, swo- } \\
\text { b o d n e } \\
\text { prowadzo- } \\
\text { ne przez } \\
\text { u c z n i ó w } \\
\text { szkół pod- } \\
\text { stawowych } \\
\text { - dokumen- } \\
\text { tacja foto- } \\
\text { graficzna }\end{array}$ \\
\hline$\frac{\vec{t}}{\underbrace{ \pm}_{I I}}$ & $\begin{array}{l}0 \\
\text { ż } \\
\text { y } \\
\text { ż } \\
z\end{array}$ & $\begin{array}{l}\text { - raport końco- } \\
\text { wy i publikacja } \\
\text { problemowa }\end{array}$ & $\begin{array}{l}\text { - publikacja } \\
\text { podsumowu- } \\
\text { jąca projekt } \\
\mathrm{i} \text { prezentująca } \\
\text { historię i trady- } \\
\text { cje Ukraińców } \\
\text { na Pomorzu } \\
\text { - konferencja } \\
\text { naukowa }\end{array}$ & $\begin{array}{l}\text { - zdeponowa- } \\
\text { nie materia- } \\
\text { łów z badań } \\
\text { w archiwum } \\
\text { CSE Świato- } \\
\text { wid } \\
\text { - publikacja } \\
\text { podsumowu- } \\
\text { jąca projekt } \\
\text { i badania }\end{array}$ & $\begin{array}{l}\text { - zdeponowa- } \\
\text { nie materiałów } \\
\text { dźwiękowych, } \\
\text { transkrypcji } \\
\text { i zdjęć w Ar- } \\
\text { chiwum Histo- } \\
\text { rii Mówionej } \\
\text { OPiP }\end{array}$ & $\begin{array}{l}\text { - raport } \\
\text { końcowy } \\
\mathrm{i} \text { artykut } \\
\text { problemo- } \\
\text { wy }\end{array}$ \\
\hline
\end{tabular}


Aleksandra Paprot-Wielopolska

\begin{tabular}{|c|c|c|c|c|c|}
\hline 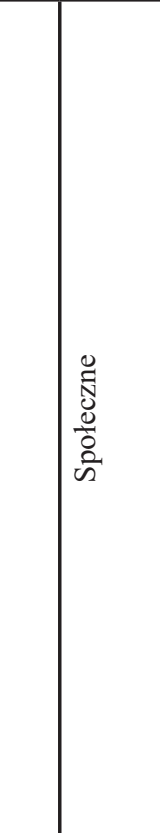 & $\begin{array}{l}\text { - upowszechnia- } \\
\text { nie zagadnień } \\
\text { z w i ą z a n y ch } \\
\text { z tożsamością } \\
\text { i specyfiką tra- } \\
\text { dycji na ob- } \\
\text { szarach post- } \\
\text { migracyjnych } \\
\text { podczas spotkań } \\
\text { i wykładów } \\
\text { w obu regionach } \\
\text { - wznowienie } \\
\text { książki dotyczą- } \\
\text { cej kultury ludo- } \\
\text { wej Powiśla }\end{array}$ & $\begin{array}{l}\text { - szkolenie } \\
\text { z zakresu NDK } \\
\text { dla przedstawi- } \\
\text { cieli lokalnych } \\
\text { instytucji i or- } \\
\text { ganizacji po- } \\
\text { zarządowych } \\
\text { p o łą c z o n e } \\
\text { z prezentacją } \\
\text { potraw regio- } \\
\text { nalnych } \\
\text { - blog doku- } \\
\text { m e n t u j ą c y } \\
\text { przebieg badań } \\
\text { terenowych }\end{array}$ & $\begin{array}{l}\text { - cykl wykła- } \\
\text { dów dotyczą- } \\
\text { cych NDK } \\
\text { w społeczno- } \\
\text { ściach lokal- } \\
\text { nych } \\
\text { - filmy doty- } \\
\text { czące NDK } \\
\text { na Warmii } \\
\text { - spotkanie } \\
\text { z miesz- } \\
\text { kańcami po- } \\
\text { wiatu pre- } \\
\text { z e n t u ją c e } \\
\text { efekty badań } \\
\text { etnologicz- } \\
\text { nych } \\
\text { - indywidual- } \\
\text { ne szkolenie } \\
\text { d oty c zą c e } \\
\text { NDK dla haf- } \\
\text { ciarki }\end{array}$ & \begin{tabular}{|lr} 
- przekazanie \\
nagrań świad- \\
kom historii \\
i ich rodzinom
\end{tabular} & $\begin{array}{l}\text { - konferen- } \\
\text { cja mło- } \\
\text { dych bada- } \\
\text { czy tradycji } \\
\text { kultu ro- } \\
\text { wych Po- } \\
\text { morza Za- } \\
\text { chodniego } \\
\text { połączona } \\
\text { z prezen- } \\
\text { tacją ku- } \\
\text { lin arió w } \\
\text { i rękodzieła }\end{array}$ \\
\hline \begin{tabular}{c}
\multicolumn{2}{c}{ Ocena } \\
w kontek- \\
ście NDzK
\end{tabular} & $\begin{array}{l}\text { - rozpozna- } \\
\text { nie lokalnych } \\
\text { i regionalnych } \\
\text { k on teks to w } \\
\text { funkcjonowa- } \\
\text { nia NDK i ich } \\
\text { kategoryzacja } \\
\text { w odniesieniu } \\
\text { d o o k r s u } \\
\text { sprzed i po } 1945 \\
\text { r. funkcjonowa- } \\
\text { nia NDK i ich } \\
\text { kategoryzacja } \\
\text { w odniesieniu } \\
\text { d o o k r s u } \\
\text { sprzed i po } \\
1945 \mathrm{r}\end{array}$ & $\begin{array}{l}\text { - dokumen- } \\
\text { tacja NDK } \\
\text { mniejszości } \\
\text { narodowej } \\
\text { - określenie } \\
\text { s p o s o b ó w } \\
\text { transmisji i ro- } \\
\text { dzajów NDK } \\
\text { w obrębie ro- } \\
\text { dziny i spo- } \\
\text { łeczności para- } \\
\text { fialnej }\end{array}$ & $\begin{array}{l}\text { - dokumenta- } \\
\text { cja i opis et- } \\
\text { nograficzny } \\
\text { NDK funk- } \\
\text { cjonującego } \\
\text { w społeczeń- } \\
\text { stwie postmi- } \\
\text { gracyjnym }\end{array}$ & $\begin{array}{l}\text { - fragmenta- } \\
\text { ryczna i po- } \\
\text { boczna doku- } \\
\text { mentacja NDK } \\
\text { - NDK jako tło } \\
\text { dla narracji bio- } \\
\text { graficznej }\end{array}$ & $\begin{array}{l}\text { - amatorska } \\
\text { i pobieżna } \\
\text { dokumen- } \\
\text { tacja NDK } \\
- \text { zwięk- } \\
\text { s z e n i e } \\
\text { świadomo- } \\
\text { ści NDK } \\
\text { w społecz- } \\
\text { nościach, } \\
\text { w których } \\
\text { zrealizo- } \\
\text { wano pro- } \\
\text { jekt }\end{array}$ \\
\hline
\end{tabular}


„My też chcemy mieć swoje tradycje”...

Projekty naukowe: autoetnografia, zaangażowanie na rzecz regionu i badania biograficzne

Pierwszy projekt „Kreowanie tożsamości regionalnej oraz lokalnej na Ziemiach Zachodnich i Północnych (ze szczególnym uwzględnieniem Żuław i Powiśla)" realizowałam w latach 2014-2017. Jego głównym celem było określenie wdrażanych przez elity lokalne i regionalne strategii kreowania tożsamości i polityk kulturalnych oraz określenie społecznej percepcji tych działań w ramach metodologii badań mieszanych (Plano Clark, Badiee 2010; Creswell 2013). Badania prowadziłam głównie na Żuławach i Powiślu, jednak w celu sprawdzenia poprawności wnioskowania i porównania wyników z innymi obszarami postmigracyjnymi wprowadziłam punkty kontrolne na Warmii (powiat braniewski) i Mazurach (powiat olecki). Ten zabieg miał pozwolić na realizację tych samych metod i technik badawczych na obszarach o zbliżonej specyfice społeczno-kulturowej.

W kontekście NDK kluczowe jest skupienie się na metodach, technikach i sposobach analizy zebranego materiału empirycznego, który na różnych poziomach prezentuje praktyki pojmowania i upowszechniania tegoż dziedzictwa. W omawianym projekcie bezpośredni kontakt z lokalnymi i regionalnymi elitami podczas wywiadów pozwolił mi zgromadzić narracje osób, które zarządzają dziedzictwem, kreują jego wizerunek i występują często jako eksperci repezentujący na zewnątrz interesy danej społeczności (Kvale 2010: 123). O ile wywiady swobodnie ukierunkowane pozwoliły określić, jakie tradycje są odtwarzane, wymyślane lub kompilowane, o tyle obserwacja uczestnicząca i autoetnografia analityczna (Anderson 2006) umożliwiła mi głębsze zrozumienie praktyk społeczno-kulturowych będących efektem upowszechniania lokalnych i regionalnych polityk kulturalnych w obszarze NDK.

Autoetnografia, czyli ,,akt autonarracji, w ramach którego narrator analizuje swoje własne przeżycia, poddaje refleksji osobiste doświadczenia życiowe, odnosząc je jednocześnie do kontekstu społecznego, w jakim się pojawiły" (Kacperczyk 2014: 37), towarzyszyła mi na każdym etapie badań. Pozwoliła ona zmienić nieco obraz metod jakościowych i interpretatywnych oraz wzbogacić je o moje osobiste doświadczenia, historie i refleksje, które pozostawały stale w relacji do obserwowanych zjawisk kultury i praktyk społecznych (Holman Jones, Adams, Ellis 2016: 21). Punktem wyjścia było więc moje „uwikłanie w teren”. Moi dziadkowie 
przyjechali na te tereny po 1945 r. jako nowi osadnicy, urodziłam się i wychowałam na Żuławach oraz od kilku lat angażuję się w działania o charakterze regionalnym, m.in. będąc wiceprezeską Stowarzyszenia „Kochamy Żuławy” w latach 2013-2019 i współpracując z otoczeniem lokalnym. Należę do drugiego pokolenia osób urodzonych na ZZiP, które zaczyna poszukiwać swoich korzeni i zadawać coraz więcej pytań o własną tożsamość w odniesieniu do wpływów kulturowych różnych grup osadników.

Działalność w stowarzyszeniu stworzyła mi możliwość dostępu do środowiska regionalistów i działaczy, którzy podczas badań terenowych zostali moimi rozmówcami. Spotkania, współpraca i relacje z nimi wpływały na przyjmowanie przeze mnie lub narzucanie mi różnych ról. Jak zauważyła Adrianna Surmiak, takie „uwikłanie” badacza w różne role wymaga od niego niekiedy większego zaangażowania nie tylko w zdobywanie wiedzy na temat danej społeczności, ale także w aktywność na jej rzecz. Ponadto stanowi wyzwanie ze względu na założenia metodologiczne i kwestie etyczne oraz wpływa na poczucie dużej odpowiedzialności, jaka spoczywa na antropologu zaangażowanym (Surmiak 2009: 179-180).

Należy jednak odróżnić zaangażowanie od aktywizmu badacza - ideologicznie zaangażowanej aktywności społecznej, która może doprowadzić do utarty krytycznego dystansu będącego podstawą poznania i rozumienia w antropologii (Brocki 2007: 177). Nie oznacza to jednak, że aktywność badacza na rzecz lokalnych społeczności tylko i wyłącznie zniekształca rozumienie obserwowanych zjawisk i praktyk kulturowych:

Zaangażowanie może oznaczać praktyczny wysiłek w budowaniu zażyłych relacji, które pozwolą na dostęp do świata ludzi nas interesujących i umożliwią ostatecznie normalną komunikację i rozumienie tego świata. Może oznaczać zwyczajne zaangażowanie w proces wytwarzania faktów etnologicznych na bazie codziennych interakcji z informatorami i tworzenie przestrzeni dialogu (Brocki 2007: 175).

Mając na uwadze to, że moje zadania jako badaczki nie powinny się łączyć z moimi zadaniami jako działaczki, w miarę możliwości oddzielałam i rozgraniczałam aktywność naukową od regionalnej. Chciałabym wskazać kilka głównych ról, które pełniłam w terenie, omówić sytuacje, w jakich miało to miejsce, oraz ocenić je:

- Mieszkanka regionu - rola, która wielokrotnie stanowiła punkt 
„My też chcemy mieć swoje tradycje”...

wyjścia dla wielu rozmów. Poszukiwanie wspólnych tematów i możliwość rozmowy o problemach lokalnych i regionalnych umożliwiały swobodną rozmowę, podczas której mogłam później łatwo przyjąć rolę badaczki. Stwarzało to jednak czasami możliwość fraternizacji.

- Działaczka regionalna/ekspert ${ }^{3}$ - rola, którą zazwyczaj przypisywano mi na koniec rozmowy. Wynikała z chęci podtrzymania kontaktu ze mną przez instytucję lub organizację. Zdarzało się bowiem, że parę miesięcy po przeprowadzeniu rozmów przedstawiciele niektórych instytucji dzwonili do mnie z prośbą o wygłoszenie wykładu dotyczącego tożsamości lub tradycji regionu Żuław i Powiśla. Mogło to wiązać się z odczytywaniem mojej aktywności badawczej w kontekście antropologii zaangażowanej jako chęci zaangażowania, stosowania pomocy czy edukacji (Sochacki 2009: $15)$.

- Członkini stowarzyszenia - rola, która w przypadku prowadzenia rozmów wśród przedstawicieli innych stowarzyszeń pozycjonowała mnie pozytywnie (kiedy organizacje te współpracowały lub znały działalność mojego stowarzyszenia - uczestniczyły w różnego typu wydarzeniach o charakterze regionalnym i lokalnym) lub negatywnie (kiedy rozmówcy początkowo dystansowali się wobec mnie, traktując jako osobę z konkurencyjnej organizacji regionalnej). Każdorazowo w takich sytuacjach próbowałam przedstawić rozmówcom moją aktualną rolę - badaczki i odciąć się od mojej aktywności w stowarzyszeniu. Ponadto w czasie prowadzenia badań terenowych starałam się ograniczyć moją aktywność w stowarzyszeniu.

- Badaczka/naukowiec - najczęściej przyjmowana przeze mnie rola, która była dla mnie nadrzędna, a według rozmówców stwarzała także możliwość wykorzystania wiedzy antropologicznej w praktykach społeczno-kulturowych o charakterze regionalnym.

Przykładowym efektem przyjmowania tych ról było zdiagnozowanie potrzeb regionalistów i nauczycieli ze szkół z Powiśla, którzy wielokrot-

${ }^{3}$ Zdaję sobie jednak sprawę, że definicja i rola eksperta na gruncie antropologii zaangażowanej nadal jest przedmiotem wielu polemik, a w związku z tym moje relacje ze środowiskiem działaczy, instytucji oraz mieszkańców ZZiP mogą budzić zastrzeżenia i wątpliwości. Niemniej jednak moim celem jest wskazanie, jak w kontekście refleksyjnej autoetnografii określone praktyki badawcze i przyjmowane role mogą wpływać na proces poznania określonych zjawisk kulturowych. 
nie podkreślali w rozmowach, że nie ma obecnie powszechnie dostępnej publikacji dotyczącej tradycji i kultury ludowej regionu. Często podczas spotkań i obserwacji uczestniczących słyszałam pytania: jakie tradycje mamy tutaj kultywować? Czy Powiśle ma jakiekolwiek tradycje, które moglibyśmy kontynuować? Wówczas odsyłałam te osoby do dorobku ks. Władysława Łęgi, który w 1933 r. opublikował swoje badania etnograficzne w książce Ziemia malborska. Kultura ludowa ${ }^{4}$.

Problemem okazała się jednak ograniczona dostępność publikacji w bibliotekach zlokalizowanych na Powiślu. Dlatego też we współpracy z Towarzystwem Miłośników Ziemi Sztumskiej i Wydawnictwem Region oraz przy wsparciu ze środków Województwa Pomorskiego przygotowaliśmy wznowienie książki ks. Łęgi (2018). Publikacja została uzupełniona o dodatkowy komentarz dotyczący współczesnej sytuacji dziedzictwa kultury ludowej i tradycyjnej na Powiślu w kontekście społeczeństwa postmigracyjnego. Książka trafiła do instytucji kultury i samorządów lokalnych w regionie, odbyło się kilka spotkań promocyjnych upowszechniających NDK Powiśla. Co ważne, regionaliści zaczęli korzystać z materiałów ks. Łęgi np. w ramach projektu „Zabawka ludowa z Powiśla"5 realizowanego przez Gminny Ośrodek Kultury w Kwidzynie, któremu towarzyszył folder informacyjny dotyczący zabawkarstwa. Zamieszczono w nim rysunek autorstwa ks. Łęgi przedstawiający wiatraczek w kształcie żaglówek z Janowa.

Drugi projekt o charakterze naukowym, który zrealizowałam na $\dot{Z} u-$ ławach (2018) w ramach praktykowania badań „wśród swoich”, czyli „antropologii u siebie” (anthropology at home) (Peirano 1998, Stanisz 2013: 181), dotyczył nagrania relacji świadków historii w ramach metody historii mówionej (oral history), która pozwala gromadzić narracje o charakterze biograficznym (Denzin 1989, Kaźmierska 1996). Według Oral History Association metoda ta to:

rejestrowany (na dowolnym nośniku audio lub wideo) wywiad narracyjny skupiony na indywidualnym doświadczeniu przeszłości, dający opowiadającemu możliwość jak najpełniejszego przekazania swego doświadczenia i podzielenia się refleksją nad nim, nieograniczony czasowo, do którego to wywiadu mówca posiada pełnię praw autorskich (Kurkowska-Budzan 2011: 11).

${ }^{4}$ Obszar ziemi malborskiej pokrywa się obecnie w znacznej mierze z obszarem Powiśla.

${ }^{5}$ Był to projekt dofinansowany ze środków Narodowego Centrum Kultury w ramach programu „EtnoPolska 2019”. 
„My też chcemy mieć swoje tradycje”...

Projekt objął dziesięć relacji biograficznych powojennych osadników, którzy po przyjeździe na Żuławy zajęli się rolnictwem i tym samym wpływali na kształtowanie się etosu pracy rolnika na Żuławach w kontekście adaptacji do obcego krajobrazu kulturowego. Zgodnie z przyjętą metodą rozmowa ze świadkami historii składała się z trzech etapów (swobodnej narracji biograficznej, pytań badacza z prośbą o uzupełnienie wybranych wątków biograficznych oraz pytań kwestionariuszowych związanych z projektem).

Badania te nie skupiały się bezpośrednio na dokumentacji NDK, chciałabym jednak podkreślić użyteczność relacji biograficznych. Uzyskanie tego rodzaju informacji było możliwe głównie podczas trzeciego etapu rozmowy, rzadziej drugiego. W trakcie rozmów kładłam nacisk na ukazanie tradycji rolniczych $w$ ramach międzygeneracyjnego przekazu kulturowego w rodzinach prowadzących dawniej własne gospodarstwa w miejscu pochodzenia oraz obecnie na Żuławach. Natomiast w pierwszej części - swobodnej narracji biograficznej, częściej w relacjach kobiet, pojawiały się barwne i dość szczegółowe opisy dotyczące NDK (por. Pałkowska 2016: 40), a zwłaszcza związanego z obrzędowością rodzinną i doroczną oraz kulinariami.

Historia mówiona, realizowana na gruncie badań biograficznych, gromadzona wśród najstarszych powojennych osadników i ludności rodzimej, która pozostała po 1945 r. na ZZiP, stwarza możliwość realizacji projektów oraz działań skierowanych na poszukiwanie i odtwarzanie tradycji wśród społeczności lokalnych. Co istotne, wiele organizacji pozarządowych i szkół realizuje projekty skupione na gromadzeniu wspomnień najstarszych mieszkańców miejscowości, np. Zespół Szkół Publicznych w Reptowie na Pomorzu Zachodnim (Janeczek, Szyndlarewicz, Śledziowska 2009). Jednak przyjęte w nich metody są często bliższe wywiadowi o charakterze dziennikarskim, co znacznie zubaża treść przekazu ustnego w kontekście relacji zawierających treści związane z tradycjami.

\section{Projekty popularnonaukowe: etnografia w praktyce i dokumentacja niematerialnego dziedzictwa kulturowego}

Kolejne zrealizowane projekty to „Wielokulturowe Pomorze: Ukraińcy i ich dziedzictwo kulturowe na Żuławach i Powiślu” (2016), „Warmio, 
quo vadis?”6 (2016-2017) oraz „Tutejsi - tradycje kulturowe Pomorza Zachodniego" (2018). Wszystkie z nich zakładały przeprowadzenie etnograficznych badań terenowych, przy czym dwa pierwsze - na Żuławach, Powiślu i Warmii - były realizowane przez lokalną organizację (Stowarzyszenie „Kochamy Żuławy”) lub instytucję (Centrum Spotkań Europejskich Światowid w Elblągu). Ponadto do prac badawczych w projekcie dotyczącym Pomorza zostali zaangażowani studenci gdańskiej etnologii, zaś do projektu realizowanego na Warmii studenci etnologii, kulturoznawstwa, socjologii i muzykologii z różnych ośrodków naukowych w Polsce. Badania miały więc w swym założeniu dotyczyć dokumentacji przejawów NDK i być prowadzone przez osoby posiadające już pewne doświadczenie terenowe, co miało wpłynąć pozytywnie na jakość zebranego materiału.

Natomiast projekt realizowany na Pomorzu Zachodnim posiadał już zupełnie odmienne założenia, ponieważ miał przede wszystkim wymiar edukacyjny i polegał na zrekrutowaniu piętnastu nauczycieli ze szkół podstawowych zlokalizowanych $\mathrm{w}$ gminach wiejskich. Następnie nauczyciele odbyli dwudniowe szkolenie z zakresu historii Pomorza Zachodniego, wybranych metod badań terenowych oraz NDK. Po szkoleniu rekrutowali oni grupę uczniów w swoich szkołach, aby w takim zespole przygotować projekt amatorskich badań etnograficznych i zrealizować je $\mathrm{w}$ ramach dokumentacji lokalnych tradycji (wybranych zjawisk) w gminie lub konkretnej wsi. W trzech omawianych projektach materiał badawczy miał posłużyć później naukowcom do przygotowania raportu i publikacji prezentującej przejawy NDK, ale przede wszystkim miał też być upowszechniany w lokalnych społecznościach za pomocą różnych form przekazu: publikacji online, konferencji popularnonaukowych, warsztatów, materiałów audiowizualnych ${ }^{7}$.

${ }^{6}$ Projekt składał się z kilku zadań związanych z dokumentacją materialnego i niematerialnego DK. Z uwagi na to, że kierowałam w nim badaniami etnograficznymi, to właśnie na nich skupię się w artykule.

${ }^{7}$ W przypadku projektu dotyczącego Ukraińców na Żuławach i Powiślu jest to blog, na którym dostępne są studenckie relacje z badań terenowych (https://wielokulturowepomorze.wordpress.com/ dostęp: 17.05.2020) oraz umieszczona na nim publikacja online (Paprot, Linda-Grycza, Buliński, 2016). W projekcie „Warmio, quo vadis?” jest to publikacja w wersji papierowej i online (Bugowska, Jarzębska, 2017), w tym anglojęzyczna, i seria filmów, zaś efekty projektu na Pomorzu Zachodnim zostały częściowo przedstawione na stronie internetowej (http://tutejsi.edu.pl/, dostęp: 17.05.2020). 
„My też chcemy mieć swoje tradycje”...

Zagadnienia, które zostały poruszone $\mathrm{w}$ omawianych projektach, obejmowały takie obszary jak: zwyczaje i obrzędy doroczne oraz rodzinne, religijność tradycyjną, obchody świeckie i lokalne uroczystości, tradycje kulinarne i rękodzielnicze, folklor muzyczny i twórców słowa, podania, opowieści i wierzenia. W przypadku projektu dotyczącego mniejszości ukraińskiej badacze zgromadzili ponadto materiał dotyczący współczesnych kontekstów funkcjonowania języka ukraińskiego w społeczności, poczucia tożsamości rozmówców oraz informacje dotyczące pochodzenia rozmówców i dzieciństwa. Ważnym aspektem badań była współpraca z lokalnymi instytucjami kultury, parafiami czy liderami społeczności, którzy jeszcze na etapie konceptualizacji badań wskazali badaczom kierunki aktywności społecznej w obszarze niematerialnego dziedzictwa kulturowego. Dlatego też ważnym elementem wszystkich projektów było „powrócenie” z wynikami badań do lokalnych społeczności, upowszechnianie wiedzy o ich dziedzictwie oraz udostępnienie materiałów etnograficznych, które wspomagałyby działania regionalistów.

Ponadto podczas realizacji projektu „Wielokulturowe Pomorze...” zorganizowano całodniowe szkolenie z zakresu NDK dla przedstawicieli lokalnych instytucji i organizacji pozarządowych, połączone z prezentacją potraw regionalnych. W ramach części warsztatowej uczestnicy na wybranych przykładach tradycji z Żuław i Powiśla opracowywali próbne wnioski o wpis na Krajową listę NDK. Podobne działanie odbyło się w Lidzbarku Warmińskim, kiedy jeszcze w czasie badań przeprowadziłam indywidualne konsultacje z zakresu Konwencji UNESCO z 2003 r. i krajowego systemu ochrony NDK dla hafciarki o korzeniach wileńskich, która odtwarza tradycję haftu na czepcach warmińskich, będących elementem stroju regionalnego. W przypadku pierwszego projektu szkolenie nie przyniosło do dziś wymiernego efektu w postaci wniosku o wpis na Krajową listę NDK. Mimo to ważny wydaje się sam fakt zwiększenia świadomości mieszkańców oraz lokalnych i regionalnych elit, a także pozytywne wartościowanie miejscowych tradycji. Natomiast na Warmii od 2020 r. prowadzone są intensywne działania promocyjne i edukacyjne mające na celu dokonanie takiego wpisu dzięki współpracy hafciarki, jej uczennic oraz miejscowej animatorki kultury, z którymi jestem w stałym kontakcie. 


\section{Rozumienie tradycji i jej praktykowanie}

Obserwując procesy społeczne i kulturowe w zakresie asymilacji czy adaptacji kulturowej wśród powojennych osadników oraz pierwszego pokolenia urodzonych już na ZZiP, można mieć wrażenie, że początkowo dziedzictwo ,zastane” postrzegane było wyłącznie w kontekście materialnym, natomiast dziedzictwo „wniesione" - jako niematerialne. Obecnie kolejne generacje mieszkańców tych terenów starają się umiejętnie łączyć ze sobą te dwa wymiary i nadawać im nowy sens, kultywując różnego rodzaju tradycje (dawne, nowe, kompilowane). Te nowe - traktować można w kontekście rozpowszechnionej już koncepcji tradycji wynalezionej Erica Hobsbawma, którą trafnie skomentował Jerzy Szacki w przedmowie do nowego wydania Tradycji. Zauważył on, że współcześnie:

(...) koniecznym warunkiem trwania czegoś jako tradycji jest rozpowszechniona w grupie wiara w to, że tak było, niekoniecznie natomiast zgodność tej wiary $\mathrm{z}$, prawdą historyczną”, która bywa zresztą w wielu przypadkach nie do ustalenia lub, nawet na pozór ustalona przez ekspertów, łatwo staje się przedmiotem niekończących się sporów, podczas których z zachowanych fragmentów składane są rozmaite i coraz to nowe całości, obfitujące w dodatki i przeinaczenia (Szacki 2001: 20).

Fragment ten wskazuje na to, że w przypadku regionów o przerwanej ciągłości kulturowej pewne fakty i źródła dotyczące przeszłości, na podstawie których pracują badacze i eksperci (np. historycy), nie zawsze są istotne dla społeczności lokalnych praktykujących, we własnym przekonaniu, jakąś tradycję. Z perspektywy antropologicznej ważne natomiast jest to, że zgodnie podzielane jest zbiorowe wyobrażenie danej społeczności dotyczące powstania i sensu przekazywania tradycji kolejnym pokoleniom.

Istnienie tradycji na ZZiP jest ponadto przejawem różnego rodzaju stanowisk społeczności i elit, które definiują elementy NDK jako istotne dla wzmacniania nowych tożsamości regionalnych. Tradycja staje się więc elementem pożądanym, co wyraża potrzebę (samo)stanowienia społeczności postmigracyjnych pośród innych zbiorowości i wspólnot regionalnych. Tym, co pobudza do działania na rzecz NDK, jest:

1. Potrzeba posiadania tradycji jako czegoś, co trzeba mieć, bo mają to inni, np. mieszkańcy regionów o kulturze długiego trwania. Ist- 
„My też chcemy mieć swoje tradycje”...

nienie tradycji ma więc eliminować pewnego rodzaju wykluczenie i stygmatyzację na tle kulturowym.

2. Wzorowanie się na wyróżnikach kulturowych regionów ościennych i odtwarzanie lub wymyślanie tradycji, które pozwolą na nowo określić tożsamość mieszkańców.

3. Tworzenie instytucji dziedzictwa kulturowego i profesjonalizacja w zakresie jego ochrony.

Pokazuje to, że praktykowanie NDK na ZZiP może mieć różne konteksty i zachodzić na wielu poziomach władzy instytucjonalnej i relacji społecznych. Dlatego chciałabym się odnieść do tekstu Emmy Watertone i Laurajane Smith, bazujących na koncepcji polityki uznania (politics of recognition) Nancy Fraser. Polityka ta charakteryzuje się parytetem partycypacyjnym i umożliwia społeczeństwu wspólne podejmowanie decyzji i współdziałanie. Jednak sektor związany z dziedzictwem kulturowym może być zdominowany obecnie przez szczególnie rozumiane pojęcie wspólnoty (community) ${ }^{8}$, które z kolei pomija to, że różne reprezentacje rzeczywistości mogą mieć duży wpływ na sposób budowania danej grupy i jej obrazu. Może to prowadzić do błędnego rozpoznania, dyskryminacji, obniżenia samooceny czy braku parytetów w ramach jakichkolwiek działań i zaangażowania na rzecz dziedzictwa. Dyskurs ten kształtuje rzeczywistość poprzez mistyfikację i naturalizację istniejących relacji władzy. Stwarza podział na uprzywilejowanych specjalistów od dziedzictwa i społeczności wykluczone, pozbawione głosu czy decyzyjności w mówieniu o tym, co jest dziedzictwem, a co nim nie jest (Watertone, Smith 2010: 9). W kontekście ZZiP można mówić często o istnieniu takich grup eksperckich (liderach, władzy lokalnej, regionalistach, naukowcach), które wykorzystują swój autorytet lub moc sprawczą, żeby w ramach zarządzania grupową identyfikacją wskazać lokalnym społecznościom sposób, w jaki należałoby rozpoznawać NDK i je praktykować. Ponadto wybierają często, jaki element dziedzictwa ma być chroniony i dlaczego. Ma być

\footnotetext{
${ }^{8}$ Koncepcja wspólnoty jako pewnego rodzaju zbiorowości, którą łączą pewne relacje, według Watertone i Smith (2014: 6-9) ma szczególną siłę, ponieważ wiąże się ona z nowymi pojęciami i pojawia się we współczesnych debatach dotyczących zagadnień wielokulturowości, praw mniejszości, autowizerunku czy sprawiedliwości społecznej. Dlatego może i powinna odcinać się od homogenizacji i być nastawiona także na różnicę, a nie wyłącznie stanowić remedium na problemy społeczne. Proponują również obalenie nostalgicznego ideału myślenia o wspólnocie, który dominuje w badaniach nad dziedzictwem kulturowym.
} 
on bowiem swego rodzaju ekspresją tożsamości mieszkańców regionu. Prowadzi to jednak często do skrzywionego i dość sztucznego obrazu tożsamości społeczności lokalnych czy danej zbiorowości regionalnej, która staje się zinstytucjonalizowana $\mathrm{w}$ procesie heritagizacji, czyli m.in. poszukiwania możliwości współczesnego wykorzystania dziedzictwa.

\section{Organizacja kultury regionalnej na Ziemiach Zachodnich i Północ- nych}

Ochrona NDK to też swego rodzaju kreowanie instytucji społecznych i wytwarzanie ekspresji dziedzictwa, które często niesie ze sobą z jednej strony ryzyko folkloryzacji, heritagizacji i komercjalizacji, a z drugiej umożliwia napływ wiedzy specjalistycznej (folklorystycznej, antropologicznej itp.) do sfery publicznej i pozwala kształtować rozumienie ekspresji wyrażanej w praktykach społeczno-kulturowych (Hafstein 2016). Dotyczy to zwłaszcza ZZiP, w których głównym problemem wydaje się określenie, co mieszkańcy mogą uznawać za swoje dziedzictwo, a co nie. Uzależnione jest to od kilku czynników, które wpływają na organizację kultury regionalnej (prezentuje to tabela 2). Na przykładzie badań własnych realizowanych na Pomorzu Zachodnim, Żuławach, Powiślu, Warmii i Mazurach mogę wskazać, że tym, co ją warunkuje, jest typ regionu i charakter jego granic, potrzeby społeczno-kulturalne, rodzaje wytwarzanych tożsamości i modele ich kreowania, a w konsekwencji regionalizm, który funkcjonuje w skali danego regionu lub większego, w miarę spójnego obszaru. 
„My też chcemy mieć swoje tradycje”...

Tabela 2. Organizacja kultury regionalnej w wybranych regionach ZZiP

\begin{tabular}{|c|c|c|c|c|}
\hline $\begin{array}{c}\text { POMORZE } \\
\text { ZACHODNIE }\end{array}$ & ŻUŁAWY & POWIŚLE & $\begin{array}{c}\text { WARMIA } \\
\text { (POWIAT } \\
\text { BRANIEWSKI I } \\
\text { LIDZBARSKI) }\end{array}$ & $\begin{array}{l}\text { MAZURY } \\
\text { (POWIAT } \\
\text { OLECKI) }\end{array}$ \\
\hline \multicolumn{5}{|c|}{ TYP REGIONU I CHARAKTER JEGO GRANIC } \\
\hline $\begin{array}{l}\text { region histo- } \\
\text { ryczny i ad- } \\
\text { ministracyjny } \\
\text { (pogranicze pań- } \\
\text { stwowo-narodowe) }\end{array}$ & $\begin{array}{l}\text { region geogra- } \\
\text { ficzny (b rak } \\
\text { cech pogranicza) }\end{array}$ & $\begin{array}{l}\text { region admi- } \\
\text { nistracyjny } \\
\text { (pogranicze } \\
\text { kulturowe i } \\
\text { regionalne) }\end{array}$ & $\begin{array}{l}\text { region historycz- } \\
\text { ny i etnograficzny } \\
\text { (pogranicze pań- } \\
\text { stwowo-narodo- } \\
\text { we oraz kulturo- } \\
\text { we i regionalne) }\end{array}$ & $\begin{array}{l}\text { region histo- } \\
\text { ryczny i et- } \\
\text { nograficzny } \\
\text { (pogranicze } \\
\text { kulturowe } \\
\mathrm{i} \text { regionalne) }\end{array}$ \\
\hline \multicolumn{5}{|c|}{ POTRZEBY SPOŁECZNO-KULTURALNE } \\
\hline \multicolumn{5}{|c|}{ potrzeba integracji i budowania wspólnoty lokalnej } \\
\hline \multicolumn{5}{|c|}{ RODZAJE TOŻSAMOŚCI } \\
\hline $\begin{array}{l}\text { tożsamości } \\
\text { lokalne }\end{array}$ & $\begin{array}{l}\text { tożsamość regio- } \\
\text { nalna i tożsamo- } \\
\text { ści lokalne }\end{array}$ & $\begin{array}{l}\text { tożsamości } \\
\text { lokalne }\end{array}$ & $\begin{array}{l}\text { tożsamość regio- } \\
\text { nalna i tożsamości } \\
\text { lokalne }\end{array}$ & $\begin{array}{l}\text { tożsamości } \\
\text { lokalne }\end{array}$ \\
\hline \multicolumn{5}{|c|}{ MODEL KREOWANIA TOŻSAMOŚCI } \\
\hline instytucjonalny & $\begin{array}{l}\text { społeczno-insty- } \\
\text { tucjonalny }\end{array}$ & instytucjonalny & $\begin{array}{c}\text { społeczno-instytu- } \\
\text { cjonalny }\end{array}$ & $\begin{array}{c}\text { instytucjonal- } \\
\text { ny }\end{array}$ \\
\hline \multicolumn{5}{|c|}{ REGIONALIZM } \\
\hline $\begin{array}{l}\text { zachodniopo- } \\
\text { morski }\end{array}$ & żuławski & powiślański & warmińsko-n & nazurski \\
\hline
\end{tabular}

Źródło: opracowanie własne

W każdym z regionów można wyróżnić dwa rodzaje narracji i poszczególne strategie oraz polityki pamięci, wokół których kreowana jest tożsamość mieszkańców. W odniesieniu do potrzeb społeczno-kulturalnych mieszkańców można stwierdzić, że główną potrzebą jest integracja i budowanie wspólnoty lokalnej. Społecznościom postmigracyjnym znacznie bliższa jest idea „małej ojczyzny” i utożsamiania się z otoczeniem lokalnym niż potrzeba identyfikacji na poziomie regionalnym. Można wysnuć też dwa podstawowe wnioski dotyczące funkcjonowania NDK na tych terenach:

- to historia regionu i jego specyfika osadnicza do $1945 \mathrm{r}$. najbardziej różnicuje regiony w obrębie $\mathrm{ZZiP}$; 
- okres po 1945 r. wskazuje na zbliżone mechanizmy istnienia tradycji, lecz można dostrzec pewne różnice w obrębie poszczególnych regionów, na które wpływają granice i położenie geograficzne, kulturowe lub administracyjne, np. sąsiedztwo z regionem o tradycjach długiego trwania lub bliskość granicy państwowej.

Wyniki analiz porównawczych wskazują na to, że regiony znajdujące się na ZZiP można badać tymi samymi metodami. Należy jednak w każdym przypadku dokonać szczegółowego rozeznania specyfiki historycznej, społecznej i kulturowej regionu do 1945 r., która często wpływa także na sposoby kreowania tożsamości na tym obszarze po II wojnie światowej.

\section{Realia Ziem Zachodnich i Północnych a krajowy system ochrony nie- materialnego dziedzictwa kulturowego}

Obecnie (czerwiec 2020) na Krajowej liście niematerialnego dziedzictwa kulturowego znajduje się ponad 41 wpisów ${ }^{9}$, w tym tylko pięć z ZZiP: gwara warmińska jako nośnik tradycji ustnych (2016), zwyczaj wodzenia niedźwiedzia na Śląsku Opolskim, kroszonkarstwo opolskie, umiejętność ręcznego malowania wzoru opolskiego (2019) i babski comber na Śląsku Opolskim (2020). O ile większość wpisów łączy się z tradycjami rodzimymi - związanymi ze społecznościami zamieszkującymi Warmię i Śląsk Opolski przed 1945 r., o tyle umiejętność malowania wzoru opolskiego na ceramice, zapoczątkowana w latach 60 . XX w., jest już pewnego rodzaju przekształceniem, które można rozpatrywać w kategoriach etnodizajnu. Pozwala to mieć nadzieję, że liczne powojenne reinterpretacje i transformacje NDK będą mogły w przyszłości być dostrzeżone i pozytywnie wartościowane.

Niestety dotychczas $\mathrm{w}$ ramach krajowego systemu ochrony, realizującego postanowienia Konwencji UNESCO z 2003 r., nie wdrożono żadnych szczególnych rozwiązań, które zajęłyby się stricte problemem postmigracyjnego NDK. Sprawia to, że system ochrony jest w pewien sposób dyskryminujący i niedostosowany do realiów tych ziem, a przez to zniechęca lokalne społeczności do podejmowania oddolnych inicjatyw na rzecz wartościowania w kraju dziedzictwa „,zastanego” i „przywiezio-

\footnotetext{
${ }^{9} \mathrm{http}: / /$ niematerialne.nid.pl/Dziedzictwo_niematerialne/Krajowa_inwentaryzacja/ Krajowa_lista_NDK/ (dostęp: 24.05.2020). 
„My też chcemy mieć swoje tradycje”...

nego". Można odnieść wrażenie, że postmigracyjne NDK w skali lokalnych nisz społeczno-kulturowych jest cenione i upowszechniane często w ramach różnorodnych działań kulturotwórczych. Natomiast na poziomie krajowym, gdzie szczególnie promowane są zjawiska $\mathrm{z}$ regionów o tradycjach długiego trwania, może ono być mniej atrakcyjne.

Konieczne wydaje się więc stworzenie osobnego programu działań skierowanych wyłącznie na tradycje ZZiP. Na podstawie projektów, które zrealizowałam, wyraźnie dostrzegam, że w społecznościach postmigracyjnych jest duża potrzeba posiadania własnych tradycji, które pozwolą stworzyć ich reprezentację na zewnątrz. Tytułowe stwierdzenie, że „my też chcemy mieć swoje tradycje", jest więc podyktowane tym, że społeczności też chcą mieć siłę sprawczą w decydowaniu o własnym NDK w kraju i legitymizowaniu jego przejawów. Dlatego tak ważne jest prowadzenie na tych terenach badań o charakterze etnograficznym, które byłyby realizowane w ścisłej współpracy (partnerstwie) z lokalnymi społecznościami, instytucjami oraz badaczami i pozwoliłyby na wspólne definiowanie dziedzictwa.

Takie rozwiązanie wpisuje się w ideę wzajemnej czy obopólnej etnografii (reciprocal ethnography) ${ }^{10}$, która może być postrzegana jako proces badawczy polegający na wspólnym zdobywaniu i dzieleniu się wiedzą. Badane społeczności mają wtedy realny wpływ na to, jak kształtowana jest ich reprezentacja na zewnątrz, co pozwala eliminować podstawową nierównowagę w zakresie wiedzy ekspertów i społeczności. Tego rodzaju dialogiczne podejście, bazujące na założeniu, że to społeczności powinny generować pytania badawcze, zaczyna prezentować np. coraz więcej muzeów na świecie (Atwood Mason, Turner 2020: 85). Ten kierunek badań może być więc kluczowy dla zmiany, która powinna zajść w krajowym systemie ochrony NDK. Jednak uważam, że wpisanie zjawisk kulturowych na Krajową listę NDK nie powinno ani determinować lokalnych inicjatyw dokumentacyjnych czy wartościowania i potrzeb depozytariuszy dziedzictwa, ani być dla nich celem samym w sobie.

${ }^{10}$ Pojęcie to częściowo można też rozumieć jako zbliżone w pewnym zakresie do „etnografii współpracującej” wg Luke’a Erica Lassitera (collaborative ethnography) czy „etnografii opartej na współpracy” lub „współpracy etnograficznej” (Pietrowiak 2014: 18-19). 


\section{BIBLIOGRAFIA:}

Angutek, D. (2018). Tradycje wytworzone rodzacej się ponowoczesności w Polsce. Bydgoszcz: Oficyna Wydawnicza Epigram.

Anderson, L. (2006). Analytic Autoethnography. Journal of Contemporary Ethnography, 35(4), 373-395.

Atwood Mason, M., Turner, R. (2020). Cultural Sustainbility. A Framework for Relationships, Understanding and Action. Journal of American Folklore, 133(527), 81-105.

Brocki, M. (2007). Antropologia zainfekowana aktywizmem. W: J. Kowalewski, W. Piasek (red.), Zaangażowanie czy izolacja? Współczesne strategie społecznej egzystencji humanistów (s. 174-180). Olsztyn: Instytut Filozofii Uniwersytetu Warmińsko-Mazurskiego,

Brzezińska, A.W., Wosińska, M. (2009). Ukraińcy na Żuławach - szok kulturowy jako wspólna pamięć i osobiste doświadczenie. W: A.W. Brzezińska (red.), Żuławy. W poszukiwaniu tożsamości (s. 49-60). Pruszcz Gdański Gdańsk: Wydawnictwo Jasne, Muzeum Narodowe w Gdańsku.

Bugowska, E., Jarzębska, A. (red.) (2017). Warmio, quo vadis? Elbląg: Centrum Spotkań Europejskich „Światowid” w Elblągu.

Ciechorska-Kulesza, K. (2009). Nowo tworzone tradycje Elbląga i Żuław Wiślanych. W: D. Rancew-Sikora, G. Woroniecka, C. Obracht-Prondzyński (red.), Kreacje i nostalgie. Antropologiczne spojrzenie na tradycje w nowoczesnych kontekstach (s. 231-241). Warszawa: Polskie Towarzystwo Socjologiczne.

Creswell, J.W. (2013). Projektowanie badań naukowych. Metody jakościowe, ilościowe i mieszane (thum. J. Gilewicz). Warszawa: Wydawnictwo Naukowe PWN.

Denzin, N.K. (1989). Interpretative Biography. Newbury Park - London - New Delhi: Sage Publications The International Professional Publishers.

Hafstein, V.Tr. (2018). Intangible Cultural Heritage as a Festival; or, Folklorization Revised. Journal of American Folklore, 131(520), 127-149.

Hobsbawm, E. (2008). Wprowadzenie. Wynajdywanie tradycji. W: E. Hobsbawm, T. Ranger (red.), Tradycja wynaleziona (tłum. F. Godyń) (s. 9-23). Kraków: Wydawnictwo Uniwersytetu Jagiellońskiego.

Holman Jones, S. (2014). Autoetnografia. Polityka tego, co osobiste (thum. M. Brzozowska-Brywczyńska). W: N.K. Davies, Y.S. Lincoln (red.), $\mathrm{Me-}$ tody badań jakościowych, t. 2 (s. 175-118). Warszawa: Wydawnictwo Naukowe PWN. 
„My też chcemy mieć swoje tradycje”...

Janeczek, L., Szyndlarewicz, M., Śledziowska, D. (2009). Drogi życia przywiodly nas do Reptowa. Reptowo: Zespół Szkół Publicznych w Reptowie.

Kacperczyk, A. (2014). Autoetnografia - technika, metoda, nowy paradygmat? O metodologicznym statusie autoetnografii. Przeglad Socjologii Jakościowej, 10(3), 32-75.

Kaźmierska, K. (1996). Wywiad narracyjny - technika i pojęcia analityczne. W: M. Czyżewski, A. Piotrowski, A. Rokuszewska-Pawełek (red.), Biografia a tożsamość narodowa (s. 61-72). Łódź: Wydawnictwo Uniwersytetu Łódzkiego.

Kubiak, H. (2007). U progu ery postwestfalskiej. Szkice z teorii narodu. Kraków: Universitas.

Kurkowska-Budzan, M. (2011). Informator, świadek historii, narrator - kilka wątków epistemologicznych i etycznych oral history. Wroctawski Rocznik Historii Mówionej, 1, 9-34.

Kurpiel, A. (2018). Strój na scenie. Funkcje stroju i jego znaczenie dla amatorskich zespołów ludowych. W: A.W. Brzezińska, A. Paprot-Wielopolska, M. Tymochowicz (red.), Współczesna problematyka badań nad strojami ludowymi (s. 149-158). „Atlas Polskich Strojów Ludowych” t. 48. Wrocław: Polskie Towarzystwo Ludoznawcze.

Kvale, S. (2010). Prowadzenie wywiadów (tłum. A. Dziuban). Warszawa: Wydawnictwo Naukowe PWN.

Kwaśniewska, A. (2016). Niematerialne dziedzictwo kulturowe na terenach postmigracyjnych (na przykładzie Pomorza). Łódzkie Studia Etnograficzne, 55, 46-79.

Murzyn-Kupisz, M. (2010). Barbarzyńca w ogrodzie? Dziedzictwo kulturowe widziane z perspektywy ekonomii. Zarzadzanie Publiczne, 3(13), 19-32.

Łęga, W. (1933). Ziemia Malborska. Kultura ludowa. Toruń: Kasa im. Mianowskiego, Warszawa: Instytut Popierania Nauki.

Łęga, W. (2018). Ziemia Malborska. Kultura ludowa (wstęp i oprac. A. Paprot-Wielopolska, K. Zdziennicki). Gdynia: Wydawnictwo Region.

Pałkowska, K. (2016). Analiza narracji wojennych kobiet. Władza sadzenia, 9 , 24-42.

Paprot, A. (2013). Niematerialne dziedzictwo kulturowe w regionach o przerwanej ciągłości kulturowej (przykład Żuław i Powiśla). W: J. Adamowski, K. Smyk (red.), Niematerialne dziedzictwo kulturowe: źródła - wartości - ochrona (s. 317-328). Lublin - Warszawa: Wydawnictwo Uniwersytetu Marii Curie-Skłodowskiej, Narodowy Instytut Dziedzictwa.

Paprot, A., Linda-Grycza, K., Buliński, T. (red.) (2016). Wielokulturowe Pomorze. Ukraińcy $i$ ich dziedzictwo kulturowe na Żuławach $i$ Powiślu. Gdańsk - Nowy Dwór Gdański: Stowarzyszenie „Kochamy Żuławy”. 
Peirano, M.G.S. (1998). When Anthropology is at Home?: The Different Contexts of a Single Discipline. Annual Review of Anthropology, 27, 105-128.

Pietrowiak, K. (2014). Etnografia oparta na współpracy. Założenia, możliwości, ograniczenia. Przegląd Socjologii Jakościowej, 10(4), 18-37.

Plano Clark, V.L., Badiee, M. (2010). Research Questions in Mixed Methods Research. W: A. Tashakkori, C. Teddlie (red.), SAGE Handbook of Mixed Method in Social and Behavioral Research (s. 275-304). Thousand Oaks, CA: Sage.

Posern-Zieliński, A. (2005). Tożsamość a terytorium. Perspektywa antropologiczna. Przegląd Zachodni, 3, 3-20.

Sakson, A. (2005). Społeczności postmigracyjne. Siedlisko. Dziedzictwo kulturowe i tożsamość społeczności na Ziemiach Zachodnich i Północnych, 1, $1-3$.

Sakson, A. (2011). Od Kłajpedy do Olsztyna. Współcześni mieszkańcy byłych Prus Wschodnich: Kraj Kłajpedzki, Obwód Kaliningradzki, Warmia i Mazury. Poznań: Instytut Zachodni.

Santera-Szeliga, J. (2017). Dziedzictwo kulturowe i rozwój społeczno-gospodarczy. Oksymoron? W: C. Obracht-Prondzyński, P. Zbieranek (red.), Pomorskie poszerzenie pola kultury. Dylematy - konteksty - działania (s. 143154). Gdańsk: Uniwersytet Gdański.

Sochacki, Ł. (2009). Antropologia zaangażowana (?). Prace Etnograficzne, 38, 7-15.

Surmiak, A. (2009). Zaangażowany antropolog. O potrzebie granic. Prace Etnograficzne, 38, 179-186.

Szacki, J. (2011). Tradycja. Warszawa: Wydawnictwa Uniwersytetu Warszawskiego.

Szyfer, A. (1996). Warmiacy. Studium tożsamości. Poznań: SAWW.

Waterton, E., Smith, L. (2010). The Recognition and Misrecognition of Community Heritage. International Journal of Heritage Studies, 16(1-2), 4-15.

\section{ŹRÓDŁA INTERNETOWE:}

Konwencja UNESCO $w$ sprawie ochrony niematerialnego dziedzictwa kulturowego, https://www.unesco.pl/fileadmin/user_upload/pdf/Konwencja_o_ ochronie_dz._niemater_2003.pdf(dostęp: 3.05.2020).

Krajowa lista niematerialnego dziedzictwa kulturowego, http://niematerialne. nid.pl/Dziedzictwo_niematerialne/Krajowa_inwentaryzacja/Krajowa_lista_NDK/ (dostęp: 24.05.2020). 
„My też chcemy mieć swoje tradycje”...

Tutejsi. Tradycje kulturowe Pomorza Zachodniego, http://tutejsi.edu.pl/ (dostęp: 17.05.2020).

Wielokulturowe Pomorze: Ukraińcy $i$ ich dziedzictwo kulturowe na Żuławach i Powiślu, https://wielokulturowepomorze.wordpress.com/ (dostęp: 17.05.2020). 